\title{
Stage-dependent modulation of Sertoli cell steroid production in dogfish (Scyliorhinus canicula)
}

\author{
P. Sourdaine and D. H. Garnier \\ Groupe d'Etude de la Reproduction chez le Mâle (INSERM CJF 91-04), Université de Rennes I, \\ Campus de Beaulieu, F-35042 Rennes cedex, France
}

\begin{abstract}
Seminiferous lobules of dogfish (Scyliorhinus canicula) testis comprise cysts formed by steroidproducing Sertoli cells associated with germ cells at an identical stage of spermatogenesis. These lobules were isolated in four populations corresponding to lobules with spermatogonia (A), spermatocytes (B), early spermatids (C) and late spermatids (D). They were used for steroid radioimmunoassay or incubated with $22 \alpha$-hydroxycholesterol or with dibutyryl cyclic AMP (dibutyryl cAMP) to measure steroid production. Our results indicate that progesterone was the major steroid in seminiferous lobules at all stages of spermatogenesis except in lobules A. Furthermore, marked changes in the distribution of steroids were observed according to the stage of spermatogenesis; progesterone, 4-androstenedione, testosterone and $17 \alpha$-hydroxy, $20 \beta$-dihydroprogesterone concentrations were highest in lobules $\mathrm{D}$, whereas dihydrotestosterone concentrations decreased during spermatogenesis. No significant stage-related change was observed for $3 \alpha$-diol and $3 \beta$-diol. Incubation experiments revealed that the isolated seminiferous lobules at all stages can synthesize steroids from hydroxycholesterol and that lobules $\mathrm{D}$ have the highest basal contents of androstenedione and testosterone. Furthermore, when dibutyryl cAMP and $10 \mu \mathrm{mol}$ hydroxycholesterol $1^{-1}$ were added together to the cultures, an enhancement of the steroid secretion was observed rather than a change in synthesis. Our results also indicated that the responsiveness of the lobules to dibutyryl cAMP varies according to the stage of spermatogenesis and to the steroid assayed. Overall, this study indicated that germ cells probably markedly influence Sertoli cell steroidogenesis in the adult dogfish testis.
\end{abstract}

\section{Introduction}

The unit structure of the dogfish testis is a seminiferous lobule made up of spermatocysts, each composed of one Sertoli cell associated with 1-64 germ cells at a given stage of spermatogenesis. The linear progression of the spermatogenic wave from the area of lobule genesis to the opposite margin of the testis where spermiation occurs results in a zonation of the testis where all the spermatogenic stages are distinctly seried and can be microdissected (Sourdaine et al., 1990).

Chieffi and Lupo Di Prisco (1961) have previously identified testosterone, 4-androstenedione, progesterone and oestradiol in dogfish testicular extracts. Incubation of testicular explants of Squalus acanthias (Simpson et al., 1964) or Scyliorhinus canicula (Kime, 1978 , 1979) with radioactive steroids has suggested a preferential $\Delta^{4}$ pathway of steroidogenesis and the principal metabolites identified from progesterone were testosterone, 4 -androstenedione, $17 \alpha$-hydroxyprogesterone, 11-deoxycorticosterone and 21-hydroxylated steroids (Simpson et al., 1964). Callard et al. (1985) have shown that testicular microsomes exhibit $17 \alpha$-hydroxylase, $\mathrm{C}_{17-20}$ lyase and aromatase activities in Squalus acanthias.

The principal site of steroid synthesis in the testis of selacians is probably the Sertoli cell. Histochemical data have shown that

Received 23 January 1992.
$3 \beta$-hydroxysteroid dehydrogenase $(3 \beta$-HSD) activity is localized in the cytoplasm of the Sertoli cell of the dogfish (Simpson and Wardle, 1967; Collenot, 1969). Dubois and Callard (1989) have demonstrated $3 \beta$-HSD, hydroxylase/lyase and aromatase activities in Sertoli cells of Squalus acanthias in vitro. Furthermore, interstitial cells of the adult dogfish testis are neither abundant nor well differentiated (Collenot, 1969; Pudney and Callard, 1984b), whereas the Sertoli cells possess all the ultrastructural features of steroidogenic cells (Collenot and Ozon, 1964; Collenot and Damas, 1980; Pudney and Callard, 1984a; Mendis-Handagama et al., 1991).

The regulation of Sertoli cell function by germ cells has been investigated in mammalian testes (see reviews by Parvinen, 1982; Sharpe, 1986; Jégou et al., 1988; Skinner, 1991; Jégou, 1991). Many of the studies performed were based on the observation of stage-dependent changes in the function of Sertoli cells. In the dogfish testis, Sertoli cells also display stagedependent variations as evidenced by the decrease in the number of oestrogen receptors (Callard et al., 1985; Ruh et al., 1986), the concentration of testicular androgen receptors (Cuevas and Callard, 1992) and by an increase in the concentration of androgen-binding protein (ABP) (Callard and Mak, 1988) during spermatogenesis. Moreover, we have demonstrated that the testicular content of progesterone, 
4-androstenedione, testosterone, dihydrotestosterone (DHT), 11 -ketotestosterone (11 KT) and of $5 \alpha$-androstane $3 \alpha, 17 \beta$-diol ( $3 \alpha$-diol) varies in a stage-dependent manner and that there are stage-related changes of steroid responsiveness of testicular explants to dibutyryl cyclic AMP (dibutyryl cAMP) (Sourdaine et al., 1990).

The aim of this study was to investigate further interactions between germ cells and Sertoli cells in the testis of dogfish by measuring Sertoli cell steroids in seminiferous lobules isolated at different stages of spermatogenesis in the presence or absence of dibutyryl cAMP or of $22 \alpha$-hydroxycholesterol.

\section{Materials and Methods}

\section{Animals}

Mature dogfish (Scyliorhinus canicula) were obtained from the Station Biologique de Roscoff (Brittany, France). The fish were kept at the Station de Physiologie des Poissons (INRA, Rennes, France), in synthetic sea-water at $13 \pm 3^{\circ} \mathrm{C}$, under a natural photoperiod.

\section{Preparation of seminiferous lobules and culture}

Dogfish were killed by section of the spinal cord. All the following operations were carried out in sterile conditions at $15^{\circ} \mathrm{C}$. Testes were removed and immediately placed in Gautron's buffer (GB, pH 7.8, 890 mosmol kg ${ }^{-1}$; Gautron, 1978) supplemented with $100 \mu \mathrm{g}$ gentamicin $\mathrm{ml}^{-1}, 50 \mathrm{IU}$ penicillin $\mathrm{ml}^{-1}$ and $50 \mu \mathrm{g}$ streptomycin $\mathrm{ml}^{-1}$ (GIBCO-BRL, France). After decapsulation, testes were cut transversely into $2 \mathrm{~mm}$ slices. Four major spermatogenic zones, namely, zone A (lobules with spermatogonia, stages I-VI of Mellinger, 1965), zone B (lobules with spermatocytes, stages VII-X), zone $\mathrm{C}$ (lobules with spermatids at early stages of spermiogenesis, stages XI-XII) and zone D (lobules with spermatids at late stages of spermiogenesis, stages XIII-XVIII), were identified and separated out from testis slices by using a dissecting microscope. These zones were then incubated in calcium- and magnesium-

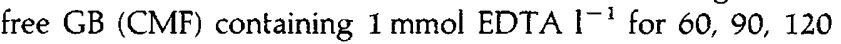
and $180 \mathrm{~min}$, respectively. Seminiferous lobules were isolated by mechanical dissociation using stainless sieves (Bioblock, France) with mesh size of $350 \mu \mathrm{m}$ for zone A or of $630 \mu \mathrm{m}$ for the other zones. Single cells and cell debris were removed by collecting dissociated lobules under a continuous running of CMF-EDTA, washed twice with CMF for each step, and allowed to sediment at unit gravity for less than $15 \mathrm{~min}$. Seminiferous lobules were then incubated in GB containing $86 \mathrm{KIU}$ DNAase $\mathrm{ml}^{-1}$ (final concentration) for $10 \mathrm{~min}$ and washed with culture medium Leibovitz-L15 (GIBCO-BRL,

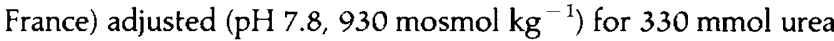
$\mathrm{l}^{-1}$ and $280 \mathrm{mmol}$ sodium chloride $\mathrm{l}^{-1}$ and supplemented with $4.6 \mathrm{mmol}$ glucose $\mathrm{l}^{-1}, 20 \mathrm{mmol}$ Hepes $\mathrm{1}^{-1}$ and $2 \%$ Ultroser (steroid free serum substitute, IBF, France).

This dissociation procedure led to the harvesting of 8000 lobules A (90-98\% purity) 5000 lobules B (75-83\% purity), 10000 lobules $C(80-89 \%$ purity) and 18000 lobules D (94$98 \%$ purity) per testis (Fig. 1). Routinely, 6-9 $\times 10^{3}$ intact seminiferous lobules were cultured in 6-well plates (NUNC; diameter of the well: $35 \mathrm{~mm}$ ) for $12 \mathrm{~h}$ in air at $15^{\circ} \mathrm{C}$, in $2 \mathrm{ml}$ culture medium, in the presence or absence of dibutyryl cAMP (Sigma, France), with or without $22 \alpha$-hydroxycholesterol (Sigma). At the end of the incubation, tissues and media were separated and stored at $-80^{\circ} \mathrm{C}$ until assayed.

\section{Steroid analysis}

Steroids. Nonradioactive steroids were purchased from Steraloids (Wilton, NH). Standard dilutions $(5-1000 \mathrm{pg}$ in $100 \mu \mathrm{l})$ were prepared in phosphate buffer from a stock methanol solution $\left(100 \mu \mathrm{g} \mathrm{ml}^{-1}\right)$. Radioactive steroids were purchased from Amersham-France (Les Ulis, France): $2.59 \mathrm{TBq}$ $\left[1,2,6,7-{ }^{3} \mathrm{H}\right]$ testosterone $\mathrm{mmol}^{-1} ; 2.96 \mathrm{TBq}\left[1,2,6,7-{ }^{3} \mathrm{H}\right]$ androst4-ene-3,17-dione $\mathrm{mmol}^{-1} ; 6.66 \mathrm{TBq} 5 \alpha$-dihydro-[1,2,5,6,7, $\left.16,17-{ }^{3} \mathrm{H}\right]$ testosterone $\mathrm{mmol}^{-1} ; \quad 1.95 \mathrm{TBq} \quad 5 \alpha-\left[1 \alpha 2 \alpha(\mathrm{n})-{ }^{3} \mathrm{H}\right]$ androstane-3 $\alpha, 17 \beta$-diol mmol ${ }^{-1} ; 1.93 \mathrm{TBq} 5 \alpha-\left[1 \alpha 2 \alpha(\mathrm{n})-{ }^{3} \mathrm{H}\right]$ androstane-3 $\beta, 17 \beta$-diol $\mathrm{mmol}^{-1} ; \quad 4 \mathrm{TBq}\left[1,2,6,7,16,17-{ }^{3} \mathrm{H}\right]$ progesterone $\mathrm{mmol}^{-1}$; labelled $17 \alpha$-hydroxy,20 $\beta$-dihydroprogesterone was prepared from $2.07 \mathrm{TBq} 17 \alpha$-hydroxy-\{1,2,6,7${ }^{3} \mathrm{H}$ ]progesterone $\mathrm{mmol}^{-1}$.

Radioimmunoassay of steroids. For each assay, the recovery was estimated by the addition of 2000 d.p.m. assayed steroid before extraction. Progesterone, 4-androstenedione, testosterone, DHT, $5 \alpha$-androstane $3 \beta, 17 \beta$-diol ( $3 \beta$-diol) and $3 \alpha$-diol were assayed in tissues and media after extraction with a cyclohexane/ethyl acetate mixture $(1 / 1, v / v)$. This was followed by separation on a celite (535) column using an isooctane-benzene mixture as eluant according to Corpechot et al. (1981) and Gamier (1985), whereas $17 \alpha$-hydroxy,20 $\beta$-dihydroprogesterone (17 $\alpha 20 \beta$ OHP) was analysed after dichloromethane extraction only. The assay of progesterone was performed according to Yenikoye et al. (1981). The mean crossreactivities of the anti-progesterone-11 $\alpha$-succinyl-bovine serum albumin were $9 \%$ with $17 \alpha$-progesterone and $3 \%$ with $20 \alpha$-hydroxyprogesterone. The intra-assay coefficient of variation was $10 \%$. Testosterone and DHT were assayed according to Garnier et al. (1978). The anti-testosterone-3-(O-carboxymethyl)oximebovine serum albumin (anti-testosterone-3-CMO-BSA) mainly crossreacted with $5 \alpha$-DHT $(60 \%), 5 \beta$-DHT $(20 \%)$, 3 $\alpha$-diol $(36 \%), 3 \beta$-diol (25\%), epitestosterone $(3.5 \%)$ and ethiocholanolone $(2.8 \%)$. The intra-assay coefficient of variation was $9 \%$. The anti- $5 \alpha$-DHT- $1 \alpha-\mathrm{CH}_{2} \mathrm{COOH}-\mathrm{BSA}$ crossreacted with $5 \beta$ DHT ( $48 \%$ ), 3 $\alpha$-diol (30\%), 3 $\beta$-diol ( $18 \%$ ), testosterone (12\%) and androsterone ( $4 \%$ ). The intra-assay coefficient of variation was $16 \%$. This antibody was also used to measure $3 \alpha$-diol concentrations. The intra-assay coefficient for this assay was $20 \%$. 3 $\alpha$-diol and $3 \beta$-diol were assayed according to Garnier (1985). Anti-3 $\beta$-diol-7-CMO-BSA was purchased from Sigma (A-0531, lyophilised) and used according to manufacturers instructions. The intra-assay coefficient of variation was $7 \%$. Androstenedione was assayed according to Carrié-Lemoine et al. (1983). The anti-4-androstenedione-11 $\alpha$-hemi-succinylbovine serum albumin crossreacted with $3 \alpha$-diol $(7 \%)$, epiandrosterone $(5 \%)$ and testosterone $(1.8 \%)$. The intra-assay coefficient of variation was $15 \%$. The assay of $17 \alpha 20 \beta \mathrm{OHP}$ was performed as described by Fostier et al. (1981). The mean crossreactivities of the anti-17 $\alpha 20 \beta O H P-3-C M O-B S A$ were 

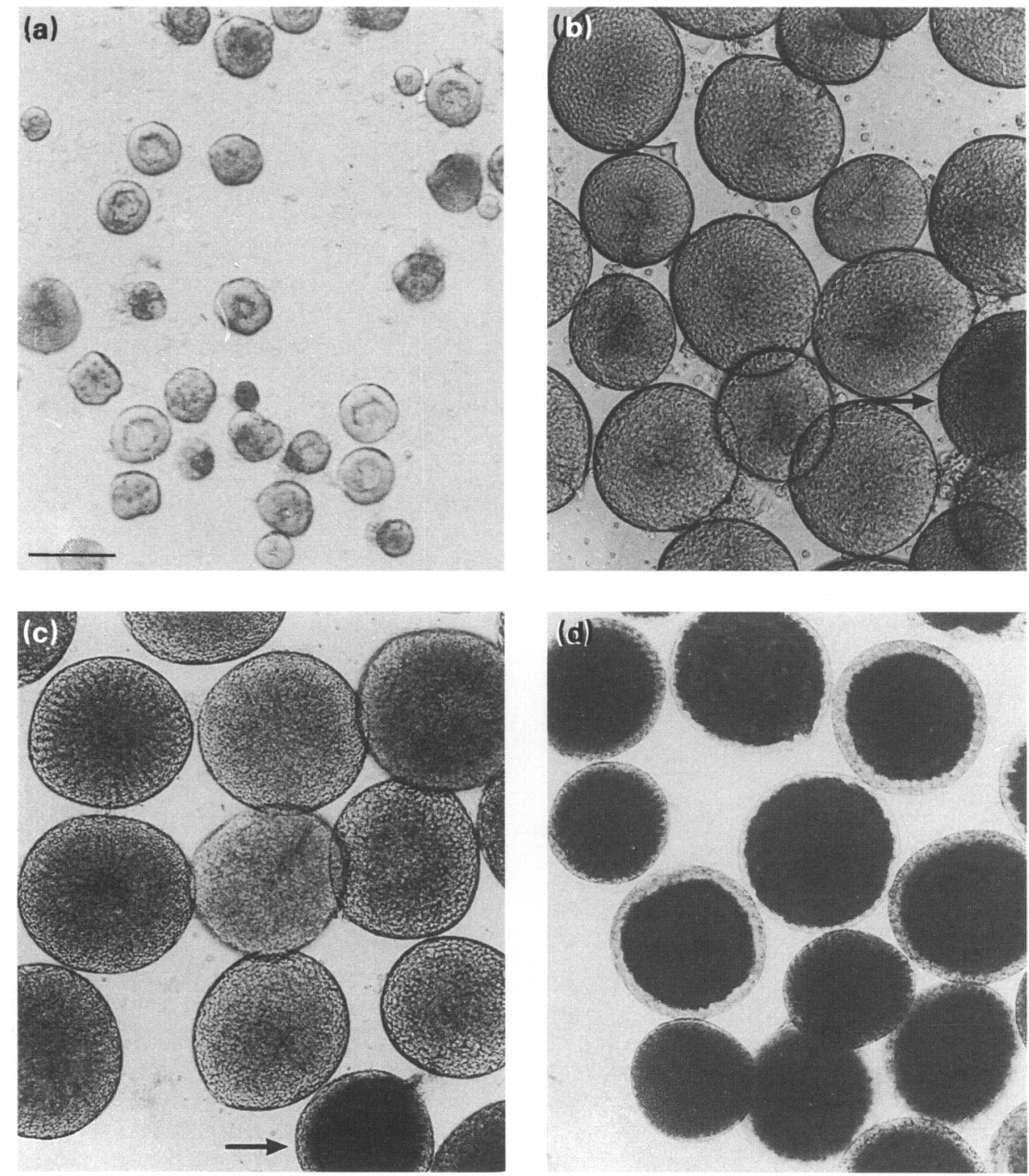

Fig. 1. Transillumination of isolated seminiferous lobules: (a) lobules with spermatogonia; (b) lobules with spermatocytes; (c) lobules with early spermatids; (d) lobules with late spermatids. Arrows show contaminating seminiferous lobules. For $(\mathrm{a}-\mathrm{d})$ bar is $180 \mu \mathrm{m}$.

$2 \%$ with $20 \beta$-dihydroprogesterone, $1 \%$ with $5 \beta$-pregnan- $17 \alpha$, $20 \beta$-diol-3-one and $1 \%$ with $17 \alpha 20 \alpha$ OHP. The intra-assay coefficient of variation was $12 \%$. Owing to the high crossreactivities of the anti-testosterone antibody (see below), the results of testosterone assay in culture media without steroid chromatography were referred to as 'androgen' concentrations. In this case, the intra-assay coefficient of variation was $7 \%$. In the case of immunoprecipitation of free steroid from bound fraction, phosphate buffer supplemented with $8 \%$ poly(ethylene glycol) was used for the centrifugation. In each experiment, all samples were measured in the same assay to avoid interassay variations. The sensitivity of the assays are indicated in the figure legends.

\section{Statistical analysis}

Data were analysed using one-way analysis of variance (ANOVA) to determine significant differences between means.

\section{Results}

Steroid content of seminiferous lobules at different stages of spermatogenesis

Large differences in the respective concentrations of steroids were observed in the seminiferous lobules of the dogfish testis (Fig. 2). In all the lobules except those with spermatogonia $(A)$, progesterone was the major steroid. As spermatogenesis progressed, an increase in the content of progesterone was observed. Lobules with late spermatids (D) showed significantly $(P<0.005)$ higher amounts of progesterone, androstenedione, testosterone and of $17 \alpha 20 \beta$ OHP than other lobules. In contrast, DHT concentrations, which were found at very low concentrations throughout spermatogenesis, decreased from lobules $\mathrm{A}$ to $\mathrm{D}$. No stagedependent variations in $3 \alpha$-diol and $3 \beta$-diol concentrations were observed. 


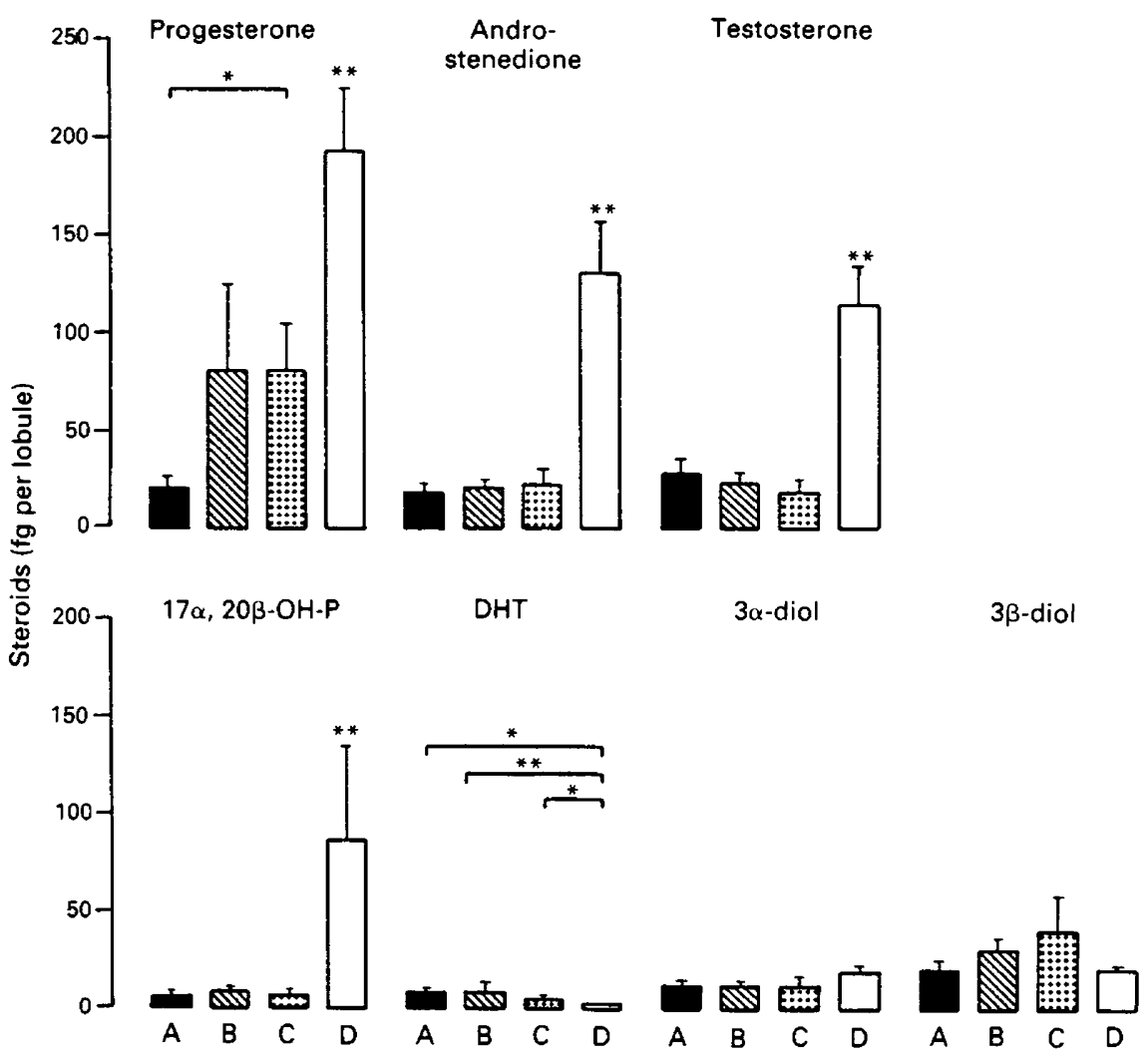

Fig. 2. Steroid contents in the seminiferous lobules of the adult dogfish isolated at different stages of spermatogenesis. A: lobules with spermatogonia, stage IV-VI of Mellinger (1965); B: lobules with spermatocytes, stages VII-X of Mellinger, 1965; C: lobules at the earliest stages of spermiogenesis, stages XI-XII of Mellinger, 1965; D: lobules at the latest stages of spermiogenesis, stages XIII-XVII of Mellinger, 1965. Values represent the means \pm SEM, $n=6$. For lobules $A$ and $C$, the sensitivity of the assay was $0.5 \mathrm{fg}$ per lobule for all steroids except for progesterone ( $1 \mathrm{fg}$ per lobule). For lobules B, the sensitivity was $0.6 \mathrm{fg}$ per lobule except for progesterone ( $1.25 \mathrm{fg}$ per lobule). For lobules $D$, the sensitivity was $0.15 \mathrm{fg}$ per lobule except for progesterone ( $0.3 \mathrm{fg}$ per lobule). $17 \alpha, 20 \beta-\mathrm{OH}-\mathrm{P}$ : $17 \alpha$-hydroxy, $20 \beta$-dihydroprogesterone; DHT: dihydrotestosterone; $3 \alpha$-diol: $5 \alpha$-androstane $3 \alpha, 17 \beta$-diol; $3 \beta$-diol: $5 \alpha$-androstane $3 \beta$, $17 \beta$-diol. If not specified by brackets, $D$ values are compared with $A, B$ and $C$ values. ${ }^{*} P<0.05$, ${ }^{* *} P<0.005$ (ANOVA).

\section{Stage-related steroid production in vitro}

Effect of 22a-hydroxycholesterol. The synthesis of progesterone (Fig. 3a), androstenedione (Fig. 3b) and testosterone (Fig. 3c) by seminiferous lobules was studied in the presence of increasing concentrations of $22 \alpha$-hydroxycholesterol $\left(0-200 \mu \mathrm{mol} \mathrm{l}^{-1}\right)$.

As shown above (Fig. 2), basal amounts of these steroids were highest in the lobules at the later stages of spermiogenesis. When $22 \alpha$-hydroxycholesterol was added, a dose-dependent increase of progesterone, androstenedione and testosterone synthesis was seen in all lobules, except in lobules with late spermatids (D), in which the increase of androstenedione and of testosterone concentrations was observed only in the culture media.

The biosynthesis of progesterone reached its maximum with $200 \mu \mathrm{mol} 22 \alpha$-hydroxycholesterol $I^{-1}$ in all the categories of lobule. Progesterone concentrations were higher in tissue than in media in lobules B to D but not in lobules A in which progesterone concentrations in media and tissues were similar. When progesterone concentrations in the medium and the tissues were added together, the maximum stimulated concentrations of this steroid, observed in the presence of $22 \alpha$ hydroxycholesterol, were higher in lobules $C$ and $B$ than in lobules $\mathrm{D}$ and $\mathrm{A}$. The factor of stimulation of progesterone biosynthesis by $22 \alpha$-hydroxycholesterol decreased during spermatogenesis (Table 1 ) and the sensitivity of the lobules to $22 \alpha$-hydroxycholesterol, represented by the concentration of $22 \alpha$-hydroxycholesterol necessary to elicit the half-maximal response of progesterone production $\left(\mathrm{ED}_{50}\right)$, decreased from lobules $\mathrm{A}$ to lobules $\mathrm{D}$ (Table 1 ).

The biosynthesis of androstenedione reached its highest values for $100 \mu \mathrm{mol} 22 \alpha$-hydroxycholesterol $\mathrm{l}^{-1}$ in lobules $\mathrm{B}$, C, D and for $200 \mu \mathrm{mol} \mathrm{l^{-1 }}$ for the lobules A (Fig. 3b). Androstenedione concentrations were higher in tissues than in media in lobules $A$ to $C$ but not in lobules $D$, where the opposite was seen. No significant change in androstenedione concentrations was observed in the tissues of lobules D. When androstenedione concentrations in the medium and the tissues were added together, the maximum stimulated concentrations 

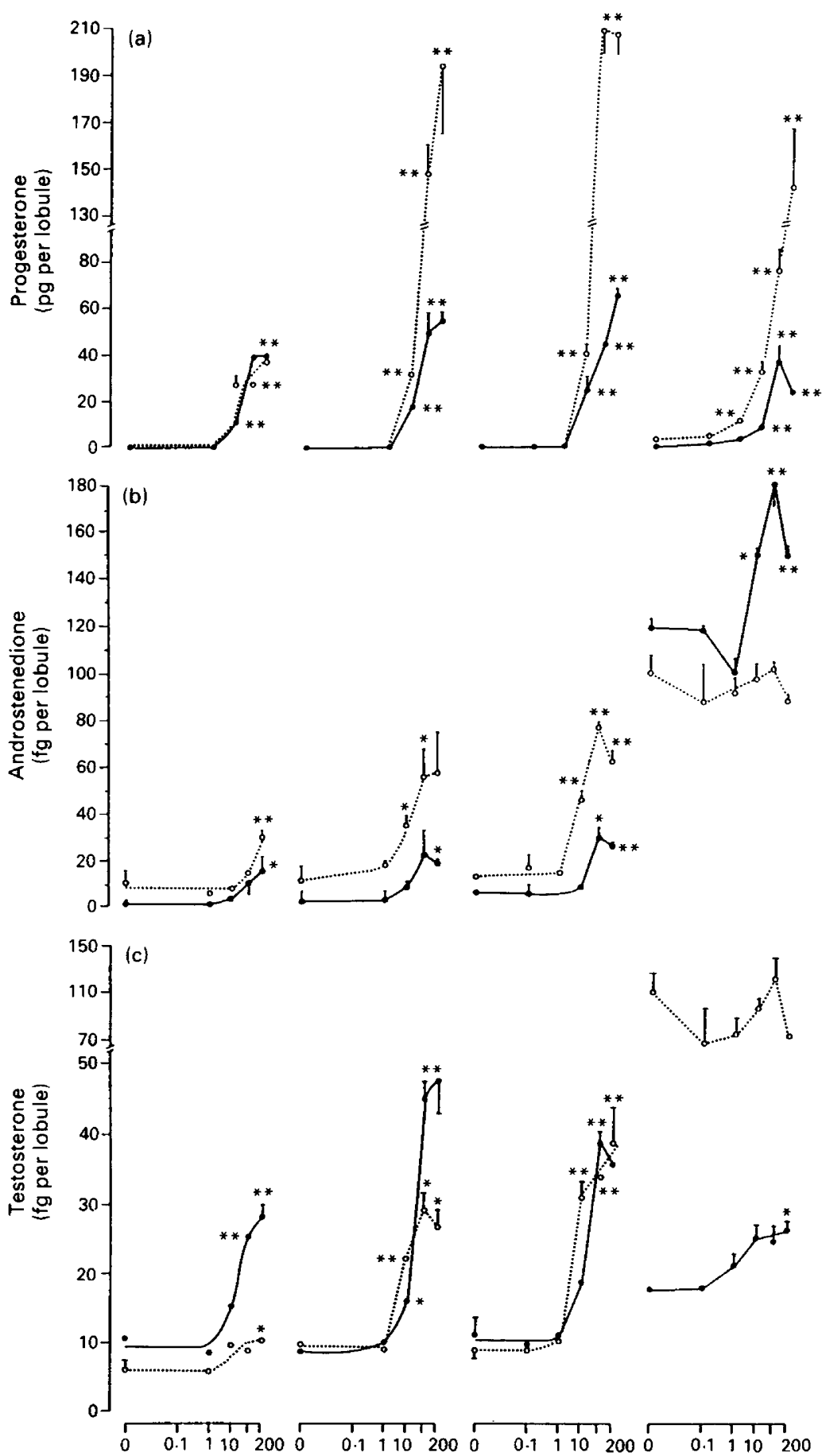

A
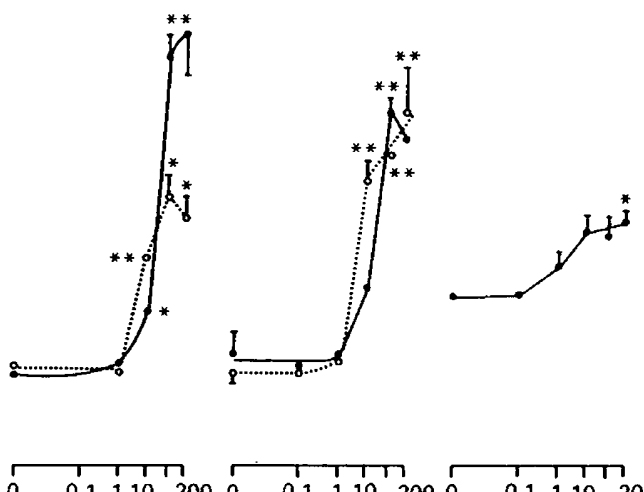

$22 \alpha$-hydroxycholesterol $\left.(\mu \mathrm{mol})^{-1}\right)$

Fig. 3. (a) Progesterone, (b) androstenedione, (c) testosterone concentrations in media $(-1)$ and tissues $(\mathrm{O}---\mathrm{O})$ from isolated seminiferous lobules (A: with spermatogonia; $B$ : with spermatocytes; $C$ : with early spermatids; $D$ : with late spermatids), incubated for $12 \mathrm{~h}$ at $15^{\circ} \mathrm{C}$, with increasing concentrations of $22 \alpha$-hydroxycholesterol. Values represent the means \pm SEM of four replicates and six dogfish. The sensitivity of the assays was $1.4 \mathrm{fg}$ per lobule for progesterone and $0.7 \mathrm{fg}$ per lobule for androstenedione and testosterone. ${ }^{*} P<0.05,{ }^{* *} P<0.005$ compared with the values obtained in absence of $22 \alpha$-hydroxycholesterol (ANOVA). 
Table 1. Characteristics of the dose-dependent curves of steroids in response to $22 \alpha$-hydroxycholesterol

\begin{tabular}{lcccc}
\hline Lobules & A & B & C & D \\
\hline Progesterone & & & & \\
Factor of stimulation & 2600 & 1450 & 900 & 40 \\
ED $_{50}\left(\mu\right.$ mol l $\left.^{-1}\right)$ & 10 & 40 & 50 & 70 \\
Androstenedione & & & & \\
Factor of stimulation & 3.5 & 4.3 & 2.4 & 1.2 \\
ED $_{50}\left(\mu\right.$ mol 1 $\left.1^{-1}\right)$ & 120 & 40 & 20 & 7 \\
Testosterone & & & & \\
Factor of stimulation & 2.4 & 4 & 3.8 & $1.4^{*}$ \\
ED $_{50}\left(\mu\right.$ mol l $\left.^{-1}\right)$ & 10 & 10 & 10 & $2^{*}$ \\
\hline
\end{tabular}

$\mathrm{ED}_{50}$ : concentration of $22 \alpha$-hydroxycholesterol necessary to elicit the halfmaximal response of steroid production. Factor of stimulation: maximum stimulated steroid concentrations divided by basal values; ${ }^{*}$ in media only.

with $22 \alpha$-hydroxycholesterol increased during spermatogenesis. The stimulatory factor of androstenedione biosynthesis was higher in lobules $B$ and $A$ than in lobules $C$ and $D$ and the sensitivity of the lobules to $22 \alpha$-hydroxycholesterol increased as spermatogenesis proceeded (Table 1).

The biosynthesis of testosterone reached a maximum with $100 \mu \mathrm{mol}$ (lobules B and C) or $200 \mu \mathrm{mol}$ (lobules A) $22 \alpha$ hydroxycholesterol $\mathrm{l}^{-1}$. In contrast to the other steroids examined, testosterone secretion was greater in the media than in the tissues for lobules $\mathrm{A}$ and $\mathrm{B}$. Testosterone concentrations in culture media of the lobules at the latest stages of spermiogenesis (D) were slightly stimulated by $22 \alpha$-hydroxycholesterol, whereas no significant change was observed in the tissues. However, the sum of testosterone concentrations in media and tissues of lobules D was higher than in the other lobules. The stimulatory factor of testosterone biosynthesis was higher in lobules $B$ and $C$ than in lobules $A$ (Table 1 ); the $E_{50}$ value was similar for these three categories of lobule.

Effect of dibutyryl cAMP on androgens. With increasing concentrations of dibutyryl cAMP, a slight dose-dependent increase in androgen concentrations was observed (Fig. 4). The factor of stimulation was 1.4 and the $\mathrm{ED}_{50}$ value was $10 \mathrm{mmol} \mathrm{l}^{-1}$. In contrast, androgen concentrations in culture media of lobules $\mathrm{A}$, $B$, and $C$ were not significantly enhanced by dibutyryl cAMP (data not shown).

Effect of dibutyryl cAMP in the presence of $10 \mu \mathrm{mol} 22 a$ hydroxycholesterol $l^{-1}$. The concentrations of progesterone (Fig. 5a), androstenedione (Fig. 5b) and testosterone (Fig. 5c) were analysed in tissues and media of seminiferous lobules, incubated in vitro with or without increasing concentrations of dibutyryl cAMP (2.5-20 $\left.\mathrm{mmol} \mathrm{l}^{-1}\right)$.

Dibutyryl cAMP could induce a slight increase of steroid concentrations in the media. In lobules A only, the highest dose tested resulted in a significant increase of progesterone (about twofold) and androstenedione (about threefold) secretion in the media. In lobules B and C, dibutyryl cAMP induced an increase in the testosterone concentrations in the media, whereas progesterone and androstenedione concentrations in tissues and

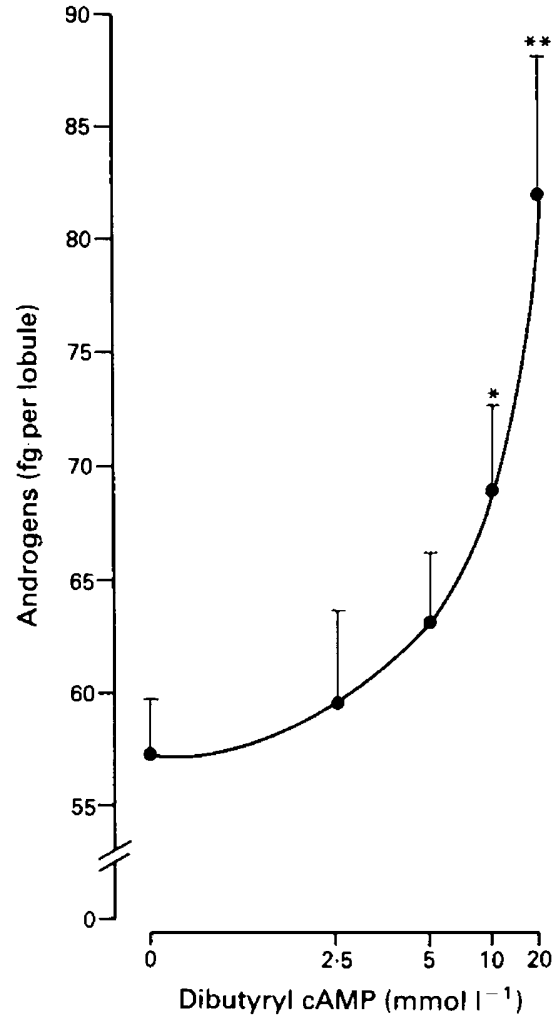

Fig. 4. Androgen concentrations in media of isolated seminiferous lobules containing last stages of spermiogenesis (lobules D) incubated for $12 \mathrm{~h}$ at $15^{\circ} \mathrm{C}$ with increasing concentrations of dibutyryl cAMP. Values represent the means \pm SEM of four replicates and four dogfish. The sensitivity of the assay was $0.6 \mathrm{fg}$ per lobule. ${ }^{*} P<0.05$, ${ }^{* *} P<0.01$ compared with the values obtained in the absence of dibutyryl CAMP (ANOVA).

media were unaffected. $\mathrm{ED}_{50}$ values were $4.5 \mathrm{mmol} \mathrm{l}^{-1}$ for lobules $\mathrm{B}$ and $10 \mathrm{mmol} \mathrm{l}^{-1}$ for lobules $\mathrm{C}$ and the stimulatory factors were 2.3 and 3 for lobules $B$ and $C$, respectively. With $20 \mathrm{mmol}$ dibutyryl $\mathrm{CAMP}^{-1}$, the maximum concentrations of testosterone were higher in the media of lobules $C$ than in the media of lobules $\mathrm{B}$. In lobules $\mathrm{D}$, dibutyryl cAMP induced a dose-dependent decrease of androstenedione in tissues and the factor of inhibition was 1.7. This decrease in androstenedione concentrations in tissues was partially due to an increase of androstenedione in medium with a factor of stimulation equal to 1.3. The factor of inhibition of the androstenedione synthesis (sum of media and tissues) was 1.2. Moreover, it appeared that the concentrations of progesterone and androstenedione were higher in the tissues than in the media except for androstenedione concentrations for lobules $\mathrm{D}$ at 10 and $20 \mathrm{mmol}$ dibutyryl cAMP $1^{-1}$. The concentrations of testosterone were similar in media and in tissues for lobules $A$ and $B$ and for lobules $C$ between 0 and $5 \mathrm{mmol}$ dibutyryl cAMP $^{-1}$, and were higher in tissues than in media for lobules $D$.

\section{Discussion}

From this work, it appears that progesterone is quantitatively the major steroid present in isolated lobules, whereas, in a 

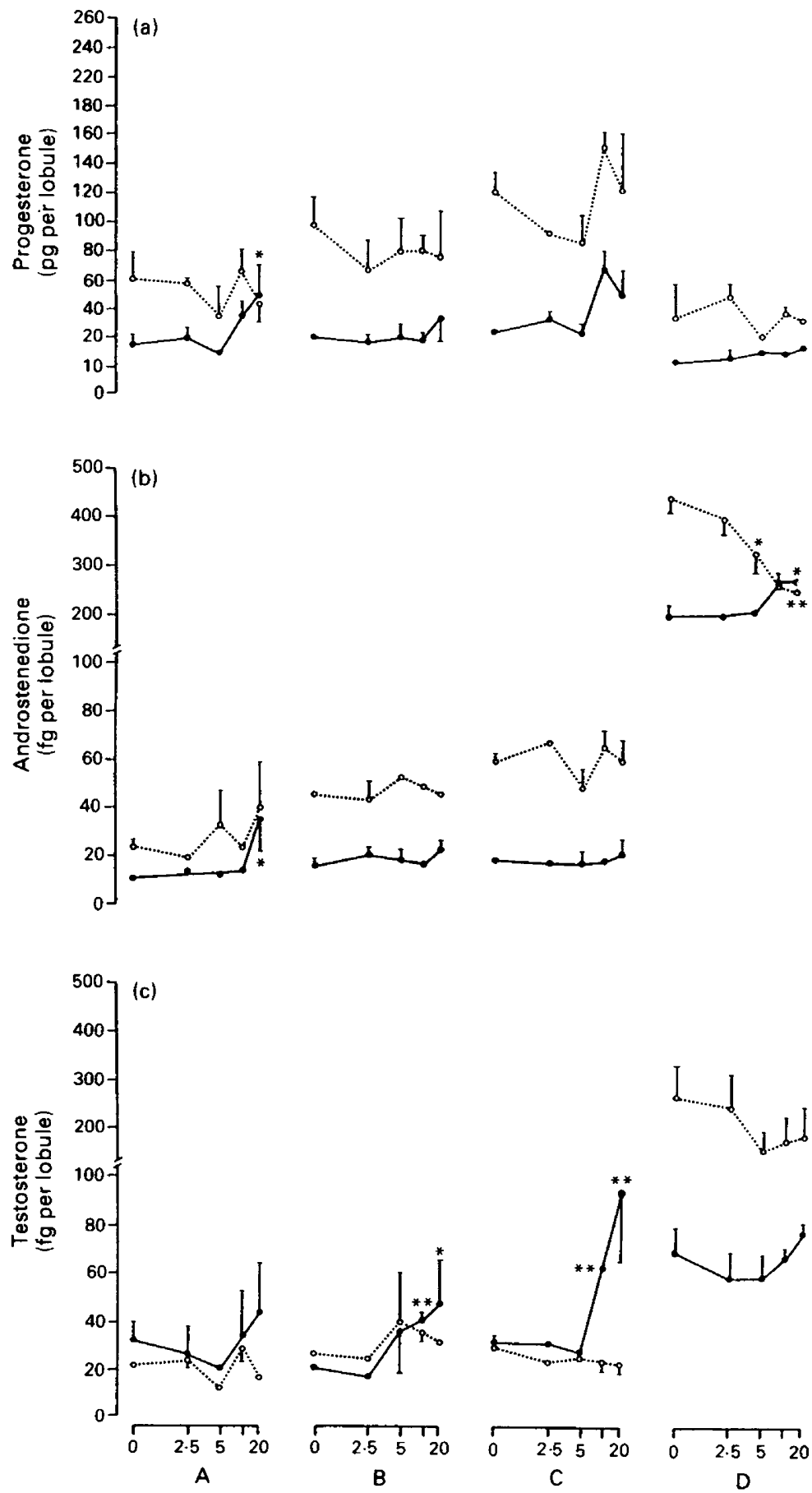

Dibutyryl cAMP (mmol $)^{-1}$ )

Fig. 5. (a) Progesterone, (b) androstenedione, (c) testosterone concentrations in media ( -1 ) and tissues $(\mathrm{O}---\mathrm{O})$ from isolated seminiferous lobules (A: with spermatogonia; $B$ : with spermatocytes; $C$ : with early spermatids; $D$ : with late spermatids), incubated for $12 \mathrm{~h}$ at $15^{\circ} \mathrm{C}$ with increasing concentrations of dibutyryl cAMP. Values represent the means \pm SEM of three replicates and six dogfish. The sensitivity of the assays was $1.6 \mathrm{fg}$ per lobule for progesterone and $0.8 \mathrm{fg}$ per lobule for androstenedione and testosterone. ${ }^{*} P<0.05,{ }^{* *} P<0.005$, compared with the values obtained in the absence of dibutyryl cAMP (ANOVA). 
previous study, testosterone was found to be the predominant steroid in tissues at all stages of spermatogenesis (Sourdaine et al., 1990). This difference can be explained by the fact that the steroids assayed in testicular tissues represent the sum of the steroids present in the seminiferous lobules plus those present in the interlobular compartment.

The stage-dependent variations of progesterone, androstenedione and dihydrotestosterone in the lobules observed here were similar to those observed in testicular tissues (Sourdaine et al., 1990). Slight differences were observed for testosterone, whereas the pattern of $3 \alpha$-diol and $17 \alpha 20 \beta$ OHP contents during spermatogenesis were different.

The increase of progesterone, androstenedione and testosterone contents occurring during the later stages of spermatogenesis parallels the rise in the number of the Sertoli cell organelles, such as agranular endoplasmic reticulum, classically considered to be involved in steroidogenesis (Collenot and Damas, 1980; Pudney and Callard, 1984b) and also with the studies of Callard and collaborators showing an increase of microsomal $3 \beta$-HSD activity during spermatogenesis (Callard et al., 1985; Dubois and Callard, 1989).

The fact that the testosterone content of the seminiferous lobules increased during the late stages of spermatogenesis suggests that there is a relationship between this steroid and spermiogenesis. This hypothesis is reinforced by the study of Callard and Mak (1988) which showed an increase of androgenbinding protein (ABP) concentrations during spermatogenesis. Moreover in rats, an increase in the concentrations of androgens (Parvinen and Ruokonen, 1982) and of the secretion of ABP (Ritzen et al, 1982) are observed in stages VII-VIII of the seminiferous epithelium which were characterized by the last steps of spermiogenesis and by spermiation. Moreover, these stages are considered androgen-dependent (Sharpe et al., 1988, 1990).

In the present study, the concentration of $17 \alpha 20 \beta$ OHP was higher in lobules collected from zone D. This is interesting, since the concentration of this steroid also increases in a teleost fish, during the period of active spermiation, in which the involvement of spermatozoa in the production of $17 \alpha 20 \beta \mathrm{OHP}$ from 17a-hydroxyprogesterone was shown (Sakai et al., 1989a, b; Loir, 1990).

The use of $22 \alpha$-hydroxycholesterol provided not only an estimation of cholesterol side chain cleavage cytochrome $\mathrm{P}_{450}$ $\left(\mathrm{P}_{450 \mathrm{sCC}}\right)$ activity but also of the various enzyme activities in the pathways leading to progesterone ( $3 \beta$-HSD), androstenedione ( $17 \alpha$-hydroxylase and $C_{17-20}$ lyase) and to testosterone (17 $\beta$ HSD). In our study, the optimum $22 \alpha$-hydroxycholesterol concentration required to elicit the maximum rates of steroidogenesis (100-200 $\mu \mathrm{mol} \mathrm{l}^{-1}$ depending on the steroid and on the nature of the lobule) was comparable to that required for rat Leydig cells (100 $\mathrm{mmol} \mathrm{I}^{-1}$, Risbridger et al., 1986). Our results also indicate that all the categories of dogfish seminiferous lobule possess the enzymes necessary for biosynthesis of progesterone, androstenedione and testosterone from cholesterol; this is in agreement with the observation of Dubois and Callard (1989) showing that $3 \beta$-HSD and hydroxylase/lyase activities are present in Sertoli cells of Squalus acanthias testis at all stages of spermatogenesis. The fact that steroid biosynthesis was dramatically increased in the presence of $22 \alpha$-hydroxycholesterol suggests that the rate-limiting step in steroidogenesis of seminiferous lobules may be the delivery of cholesterol to $P_{450 \text { scc }}$ cytochrome. Whereas this study shows that the dogfish seminiferous lobules can synthesize progesterone, androstenedione and testosterone from 22 $\alpha$-hydroxycholesterol, other studies have shown that the rat seminiferous tubules cannot convert cholesterol to androgens (Hall et al., 1969; Cooke et al., 1972) and that rat Sertoli cells cannot convert pregnenolone to progesterone (Wiebe et al., 1988).

In this study, testosterone production by the lobules at the late stages of spermiogenesis was neither enhanced by $22 \alpha$ hydroxycholesterol nor by dibutyryl cAMP but its contents remained largely higher in these lobules than in the other lobules. One possible explanation is that the basal steroidogenic activity of Sertoli cells in lobules D was already maximally stimulated, and therefore, could not be stimulated further. This may result from the fact that testosterone can exert an inhibitory effect on steroidogenic enzymes such as $3 \beta$-HSD, $17 \alpha$ hydroxylase or 17 $\beta$-HSD (Van der Molen and Rommerts, 1981) or on $3 \beta$-HSD and $17 \alpha$-hydroxylase mRNA, as shown by Payne and Sha (1991). We have also observed that dibutyryl cAMP associated with $10 \mu \mathrm{mol} 22 \alpha$-hydroxycholesterol $1^{-1}$ induced a dose-dependent decrease of androstenedione synthesis in lobules $\mathrm{D}$ which was not translated into an increase of testosterone synthesis. This result is apparently in contradiction with the dose-dependent increase of 'androgen' concentrations in culture media in lobules $D$ stimulated by dibutyryl cAMP only. One possible explanation is that dibutyryl cAMP may increase a steroid other than testosterone. This steroid may be $3 \alpha$ - or $3 \beta$ diol, the contents of which were not negligible in seminiferous lobules, since these steroids crossreacted with the testosterone anti-sera ( $36 \%$ and $25 \%$ for $3 \alpha$-diol and $3 \beta$-diol, respectively). The lack of increase of progesterone concentrations in tissues and media of lobules incubated with dibutyryl cAMP and $10 \mu \mathrm{mol}$ hydroxycholesterol $1^{-1}$ may be because of an absence of progesterone biosynthesis or result from rapid metabolism of this steroid to other steroids, for example $17 \alpha 20 \beta$ OHP which was present in substantial amounts of lobules D. However, Kime (1978) and Cuevas and Callard (1992) showed that a sulfotransferase activity was present in dogfish testicular tissues. In a preliminary study, we observed that the concentrations of total androgen were similar to the concentrations of free androgen in blood plasma as well as in testicular tissues (data not shown). We therefore did not assay conjugated steroids in the present study. However, we have observed that the concentrations of conjugated $17 \alpha 20 \beta \mathrm{OHP}$ were higher than free $17 \alpha 20 \beta \mathrm{OHP}$ in blood plasma (data not shown). From these observations, a study of free and conjugated metabolites, from incubation experiments of isolated seminiferous lobules with radioactive precursor steroids, would be useful to clarify the in vitro steroidogenesis of seminiferous lobules in the dogfish.

The presence of peroxisomes in Sertoli cells of the dogfish (Mendis-Handagama et al., 1991) and the dramatic increase of their volume per seminiferous lobule during the late stages of spermiogenesis (S. Mendis-Handagama, personal communication) reinforce the fact that Sertoli cells in lobules at the late stages of spermiogenesis possess their maximum steroidogenic capacity as previously suggested by several studies (Collenot and Ozon, 1964; Collenot and Damas 1980; Pudney and Callard, 1984a; Callard et al., 1985; Dubois and Callard, 1989). 
The responsiveness of lobules $\mathrm{D}$ for the secretion of androstenedione and testosterone in response to the $22 \alpha$ hydroxycholesterol or for the secretion of androgens in response to the dibutyryl cAMP were relatively low (1.2 to 1.4) and were similar to that obtained when whole testicular tissues were used (Sourdaine et al., 1990). The fact that dibutyryl cAMP could not enhance testosterone secretion in culture media of lobules $D$ incubated with $10 \mu \mathrm{mol} 22 \alpha$-hydroxycholesterol $1^{-1}$ can be explained by the fact that the secretion of this steroid was already maximally stimulated by this dose of hydroxycholesterol. It appears that dibutyryl cAMP enhanced only the secretion of progesterone (lobules $A$ ), androstenedione (lobules $A$ and $D$ ) or testosterone (lobules $B$ and C), but not the synthesis of these steroids. It is possible that the production of androgens by the testis of selacians is independent, to some extent, of the pituitary. This view is supported by the fact that total hypophysectomy produces only a slight decrease in plasma testosterone concentrations in S. canicula (Dobson and Dodd, 1977), as observed in Torpedo marmorata and T. ocellata by Fasano et al. (1989). This highlights the importance of the contribution of testicular paracrine mechanisms and, in particular, the effects of germ cells for the control of steroid production.

In conclusion, this study establishes first, that the steroid content of seminiferous lobules varies according to the stage of spermatogenesis considered; second, isolated seminiferous lobules at all stages of spermatogenesis can synthesize steroids from hydroxycholesterol; third, dibutyryl cAMP enhances steroid secretion rather than steroid biosynthesis; fourth, the responsiveness of the lobules to dibutyryl cAMP varies according to the stage of seminiferous lobules and to the steroid assayed; fifth, lobules at the last stages of spermatogenesis have a higher basal steroidogenic activity than the lobules at other stages.

The authors wish to thank J. Chauvin for her technical assistance and M. Mathelier for the preparation of the figures, A. Fostier (INRA, Rennes) for preparation of labelled $17 \alpha$-hydroxy, $20 \beta$-dihydroprogesterone, $A$. Fostier and M. Terqui (INRA, Tours) for their gift of antisera and B. Jégou and $V$. Syed for their helpful discussions and the critical reading of this manuscript. We are also indebted to the fishermen of the Station Biologique de Roscoff (Brittany, France) and to the Station de Physiologie des Poissons (INRA, Tours) for the care of the animals. Steroid analysis was performed at the Centre de Radioimmunologie-Stéroides de l'Université de Rennes I. This work was supported by grants from INSERM (874010 and 900406).

\section{References}

Callard GV and Mak P (1988) Characteristics and stage-dependent distribution of a novel steroid binding protein in the testis of Squalus acanthias Steroids $\mathbf{5 2}$ $359-360$

Callard GV, Pudney JA, Mak P and Canick JA (1985) Stage-dependent changes in steroidogenic enzymes and estrogen receptors during spermatogenesis in the testis of the dogfish Squalus acanthias Endocrinology 117 1328-1335

Carrié-Lemoine J, Garnier DH and Richard-Yris MA (1983) Evolution des taux plasmatiques de testostérone et de 4-androstènedione chez le coq Hubbard en croissance Comptes Rendus Académie des Sciences Paris Série 3296 701-706

Chieffi $G$ and Lupo di Prisco $C$ (1961) Identification of oestradiol-17 $\beta$, testosterone and its precursors from Scyliorhinus stellaris testes Nafure 190 169-170

Collenot G (1969) Apparition et évolution de l'activité endocrine du testicule de Scyliorhinus canicula L. (Elasmobranche) Annales d'Embryologie et Morphologie 2 461-477
Collenot G and Damas D (1980) Etude ultrastructurale de la cellule de Sertoli au cours de la spermiogenèse chez Scyliorhinus canicula L. Cahiers de Biologie Marine 21 209-219

Collenot $G$ and Ozon R (1964) Mise en évidence biochimique et histochimique d'une $\Delta^{5} 3 \beta$-hydroxystéroïde-déshydrogénase dans le testicule de Scyliorhinus canicula L. Bulletin Société Zoologique de France 89 577-587

Cooke BA, de Jong FH, van der Molen HJ and Rommerts FFG (1972) Endogenous testosterone concentrations in rat testis interstitial tissue and seminiferous tubules during in vitro incubations Nature, New Biology 237 255-256

Corpéchot C, Baulieu EE and Robel P (1981) Testosterone, dihydrotestosterone and androstanediols in plasma, testes and prostates of rats during development Acta Endocrinologica 96 127-135

Cuevas ME and Callard GV (1990) Characteristics and stage-dependent distribution of a putative androgen receptor in nuclear extracts of dogfish testis Proceedings of the Endocrine Society 72 nd Annual Meeting, June 20-23, Abstract 402

Cuevas ME and Callard GV (1992) Androgen and progesterone receptors in shark (Squalus) testis: characteristics and stage-related distribution Endocrinology 130 2173-2182

Dobson S and Dodd JM (1977) Endocrine control of the testis in the dogfish Scyliorhinus canicula L. I. Effects of a partial hypophysectomy on gravimetric, hormonal and biochemical aspects of testis function General and Comparative Endocrinology 32 41-52

Dubois W and Callard GV (1989) Role of the Sertoli cell in spermatogenesis: the Squalus testis model Fish Physiology and Biochemistry 7 221-227

Fasano S, Pierantoni R, Minucci S, Di Matteo L, D'Antonio M and Chieffi G (1989) Effects of intratesticular injections of oestradiol and gonadotropinreleasing hormone ( $\mathrm{GnRH}, \mathrm{HOE} 766)$ on plasma androgen levels in intact and hypophysectomized Torpedo marmorata and Torpedo ocellata General and Comparative Endocrinology 75 349-354

Fostier A, Jalabert B, Campbell C, Terqui M and Breton B (1981) Cinétique de la libération in vitro de la $17 \alpha$-20 $\beta$-dihydroprogestérone par des follicules de Truite arc-en-ciel, Salmo gairdneri Comptes Rendus Académie des Science Paris Series 3292 777-780

Garnier DH (1985) Androgen and estrogen levels in the plasma of Pleurodeles walt Michah, during the annual cycle. I. Male cycle General and Comparative Endocrinology 58 376-385

Garnier DH, Cotta Y and Terqui M (1978) Androgen radioimmunoassay in the ram: results of direct plasma testosterone and dehydroepiandrosterone measurement and physiological evaluation Annales de Biologie Animale 18 265-281

Gautron J (1978) Effet du calcium et de la stimulation sur les terminaisons nerveuses des fonctions nerf-électroplaque de la Torpille Biology of the Cell 31 $31-44$

Hall PF, Irby DC and de Kretser DM (1969) Conversion of cholesterol to androgens by rat testes: comparison of interstitial cells and seminiferous tubules Endocrinology 84 488-496

Jégou B (1991) Spermatids are regulators of Sertoli cell function. In The Male Germ Cell: Spermatogonium to Fertilization Ed. B Robaire. Annals of the New York Academy of Sciences 637 340-353

Jégou B, Le Magueresse B, Sourdaine P, Pineau C, Velez de la Calle JF, Garnier DH, Guillou F and Boisseau C (1988) Germ cell-Sertoli cell interactions in vertebrates. In Molecular and Cellular Endocrinology of the Testis Vol 50 pp 255-270 Eds BA Cooke and RM Sharpe. Serono Symposia Publications, Raven Press, New York

Kime DE (1978) Steroid biosynthesis by the testis of the dogfish Scyliorhinus caniculus General and Comparative Endocrinology 34 6-17

Kime DE (1979) Androgen biosynthesis in teleost and elasmobranch fishes Proceedings of the Indian National Science Academy B45 429-435

Loir M (1990) Trout steroidogenetic testicular cells in primary culture. II. Steroidogenic activity of interstitial cells, Sertoli cells, and spermatozoa General and Comparative Endocrinology 78 388-398

Mellinger J (1965) Stades de la spermatogénèse chez Scyliorhinus caniculus (L.): description, données histochimiques, variations normales et expérimentales Zeit schrift fur Zellforschung 63 653-673

Mendis-Handagama SMLC, Sourdaine P, Garnier DH and Jégou B (1991) Peroxisomes play a significant role in testicular steroidogenesis: further evidence from Sertoli cells in the dogfish testis (Scyliorhinus canicula) 11th North American Testis Workshop, McGill University, Montréal, Canada, April 24-27, Abstract 82

Parvinen M (1982) Regulation of the seminiferous epithelium Endocrine Reviews $3404-417$ 
Parvinen $M$ and Ruokonen A (1982) Endogenous steroids in rat seminiferous tubules. Comparison of different stages of the epithelial cycle isolated by transillumination-assisted microdissection Joumal of Andrology 3 211-220

Payne $A H$ and Sha $L$ (1991) Multiple mechanism for regulation of $3 \beta$-hydroxysteroid dehydrogenase $/ \Delta^{5}-\Delta^{4}$-isomerase, $17 \alpha$-hydroxylase $/ C_{17-20}$ lyase cytochrome $\mathrm{P}_{450}$ and cholesterol side chain cleavage cytochrome $\mathrm{P}_{450}$ messenger ribonucleic acid levels in primary cultures of mouse Leydig cells Endocrinology 129 1429-1435

Pudney JA and Callard GV (1984a) Development of agranular reticulum in Sertoli cells of the testis of the dogfish Squalus acanthias during spermatogenesis Anatomical Record 2093 1-321

Pudney JA and Callard GV (1984b) Identification of Leydig-like cells in the testis of the dogfish Squalus acanthias Anatomical Record 209 322-330

Risbridger GP, Jenkins G and de Kretser DM (1986) The interaction of hCG hydroxysteroids and interstitial fluid on rat Leydig cell steroidogenesis in vitro journal of Reproduction and Fertility $77239-245$

Ritzen EM, Boitani C, Parvinen M, French FS, Feldman M (1982) Stagedependent secretion of ABP by rat seminiferous tubules Molecular and Cellular Endocrinology 25 25-33

Ruh MF, Singh RK, Mak P and Callard GV (1986) Tissue and species specificity of unmasked nuclear acceptor sites for the estrogen receptor of Squalus testes Endocrinology $118811-818$

Sakai N, Ueda H, Suzuki N and Nagahama Y (1989a) Steroid production by Amago Salmon (Oncorhynchus rhodurus) testes at different developmental stages General and Comparative Endocrinology 75 231-240

Sakai N, Ueda H, Suzuki N and Nagahama $\mathbf{Y}(1989 \mathrm{~b})$ Involvement of sperm in the production of $17 \alpha, 20 \beta$-dihydroxy-4-pregnen-3-one in the testis of spermiating rainbow trout, Salmon gairdneri Biomedical Research 10 131-138
Sharpe RM (1986) Paracrine control of the testis Clinical Endocrinology and Metabolism 15 185-207

Sharpe RM, Fraser HM and Ratnasooriya WD (1988) Assessment of the role of Leydig cell products other than testosterone in spermatogenesis and fertility in adult rats Intemational Journal of Andrology 11 507-523

Sharpe RM, Maddocks S and Kerr JB (1990) Cell-cell interactions in the control of spermatogenesis as studied using Leydig cell destruction and testosterone replacement American Journal of Anatomy 188 3-20

Simpson TH and Wardle CS (1967) A seasonal cycle in the testis of the spurdog Squalus acanthias, and the sites of $3 \beta$-hydroxysteroid dehydrogenase activity Joumal of Marine Biology Association UK 47 699-708

Simpson TH, Wright RS and Hunt SV (1964) Steroid biosynthesis in the testis of dogfish (Squalus acanthias) Journal of Endocrinology 31 20-38

Skinner MK (1991) Cell-cell interactions in the testis Endocrine Reviews 12 45-77

Sourdaine P, Garnier DH and Jégou B (1990) The adult dogfish (Scyliorhinus canicula L.) testis: a model to study stage-dependent changes in steroid levels during spermatogenesis Journal of Endocrinology 127 451-460

Van der Molen HJ and Rommerts FFG (1981) Testicular steroidogenesis. In The testis, pp 213-238 Eds H Burger and D de Kretser. Raven Press, New York

Wiebe JP, Buckingham KD, Wood PH and Campbell SMC (1988) Relative steroidogenic activity of Sertoli and Leydig cells and role of the Sertoli cell steroid, $3 \alpha$-hydroxy-4-pregnen-20-one, in spermatogenesis and FSH secretion. In Development and Function of the Reproductive Organs Vol II pp 39-53 Eds M Parvinen, I Huhtaniemi and LJ Pellinemi. Serono Symposia Review, Rome

Yenikoye A, Mariana IC, Ley JP, Jolivet E, Terqui $\mathbf{M}$ and Lemon-Resplandy $M$ (1981) Modèle mathématique de l'évolution de progestérone chez la vache: application et mise en évidence de différences entre races. Reproduction Nutrition Développement 21 561-575 